\title{
Differences in Motivation between Male and Female in Slovakia in
} 2015

\author{
Miloš Hitka ${ }^{1}$, Milota Vetráková ${ }^{2} \&$ Žaneta Balážová $^{3}$ \\ ${ }^{1}$ Faculty of Wood Sciences and Technology, Technical University in Zvolen, Slovakia \\ ${ }^{2}$ Faculty of Economics, Matej Bel University, Slovakia \\ ${ }^{3}$ Institute of Foreign Languages, Technical University in Zvolen, Slovakia \\ Correspondence: Miloš Hitka, Department of Enterprise Management, Faculty of Wood Sciences and Technology, \\ Technical University in Zvolen, T. G. Masaryka 24, Zvolen, Slovakia. E-mail: milos.hitka@tuzvo.sk
}

Received: August 30, 2015

Accepted: September 18, 2015

Online Published: December 22, 2015

doi:10.5539/mas.v10n1p52

URL: http://dx.doi.org/10.5539/mas.v10n1p52

\begin{abstract}
Meeting human needs or life's challenges, internal and external environments as well as some further factors affect motivation significantly. All factors are interconnected to each other and they create mutually connected parts of network. In the paper we mention the issue of motivational differences between male and female in Slovakia in the year 2015. Sampling unit contains 4,099 respondents. Deep knowledge of the differences plays a key role in employee job performance and affects the employees' motivation effectively. Results of the social inquiry confirm great similarity between motivation factors of male and female in Slovakia in 2015. Despite small significant differences we can state that there is a possibility of creating unified motivation programme for employees regardless of gender. Specific gender differences in the level of motivation have to be taken into account in order to increase motivation. In the future meeting the needs of employees can cause the changes in their motivation requirements. Therefore we suggest the organisation to update motivation programme from time to time.
\end{abstract}

Keywords: motivation, motivation programme, t-test, gender, differences in work motivation

\section{Introduction}

Employee motivation plays an important role in the enterprise management. It is determined by social and physical environment associated with the work performed (Sharlyn, 2005; Ramlall, 2004; Srivastava et al., 2008). Research and experience suggest that motivation is a dynamic state that can fluctuate over time and in relation to different situations, rather than a static personal attribute. Dynamic power affects personal behaviour and activities (Kucharčíková, 2014) and can be described by direction and intensity. High-level performance achieved permanently is the main aim of motivation. The best form of motivation is built in context of the enterprise strategy (Hitka et al., 2015; Vaníčková, 2015), enterprise management level (Závadská et al. 2013). Managers create such an environment that affects employee motivation in positive way (Grazulis \& Baziene, 2009). At the present time effective utilisation of human resources is a significant source of competitive advantage of individual enterprises (Syed et al., 2012). Factors affecting employee performance are mentioned by Hitka (2009). He divides them into: organisation, ergonomics and the impact of human resource management. Employee motivation is one of the factors as well and according to Bedrnová and Nový (2002) we understand it as "the human-centred approach to work and to specific work tasks, i.e. the particular form of willingness to work is explained by it." The process of motivation starts with the employee negative perception of working conditions (Potkány \& Stachová, 2015), whereupon they try to reduce the negative effects, whereby there is a change in the decision-making process that covers intensity level of activity, the persistence to overcome obstacles and the behaviour and action tendency (Kropivšek et al., 2011). Subsequently, a real activity, it means employee performance starts. Enterprises are involved in the motivation process twice. Firstly, they are involved in the decision- making process about intensity, quality, direction and persistence of an activity (Potkány et al., 2012; Hitka \& Štípalová, 2011; Kostiviarová \& Sopková, 2009). In the case, an employee is influenced by prior experience, i.e. the experience gained at work we can speak about intangible performance incentives (Stacho et al., 2013; Zámečník, 2007). Secondly, we can speak about tangible performance incentives-monetary or non-monetary following the employee performance (Fuchsová \& Kravčáková, 2004). Personal success, enjoyment of the job and self-awareness for achieving tasks and goals of their own as well as those of the enterprise are the essential aspects of the effective employee motivation and of the 
meeting the needs of employees (Kampf \& Bucháčková, 2005). In the paper we analyse differences in the level of motivation and its relationship with gender in Slovak enterprises in 2015.

\section{Method}

Following the research we detected the differences in motivation between male and female. Equality of averages of two primary sampling units was tested using the survey analysis and the application of the Student's T-test (Scheer, 2007). The goal-setting questionnaire was used to determine the level of motivation and the analysis of motivation factors. The questionnaire was designed in order to study staff motivation since the year 2009; it consists of 30 closed questions (Hitka, 2008). The questionnaire was divided into two parts. Socio-demographic and qualification characteristics of employees were searched in the first part. Basic data about respondents relating to their age, sex, seniority, completed education and job position were obtained in this part. The second part consisted of individual motivation factors through which information about work environment, working conditions, applied appraisal and reward system, about personnel management, health and social care system and system of employee benefits as well as information about employee satisfaction or dissatisfaction, value orientation, relation to work and enterprise or co-workers' relationship in the enterprise can be found out. Motivation factors are in alphabetical order not to affect respondents' decision. In the questionnaire respondents evaluated individual motivation factors by one of the five levels of importance from a pre-defined 5-point rating scale, 5-very important and 1-unimportant (Table 1).

Table 1. Scale of the order of motivation factors according to their importance

\begin{tabular}{lccccc}
\hline & $\mathbf{5}$ & $\mathbf{4}$ & $\mathbf{3}$ & $\mathbf{2}$ & $\mathbf{1}$ \\
\hline Desired level of motivation & very important & important & medium important & slightly important & unimportant \\
Current level of motivation & very satisfied & satisfied & neutral & slightly satisfied & unsatisfied \\
\hline
\end{tabular}

Source: Hitka, 2009.

Statistical characteristics, which compressed information about studied primary sampling units into smaller number of numerical characteristics and made mutual comparison of sampling units easier, were computed for each motivation factor. Each motivation factor was described in summary by basic characteristics of size and variability of quantitative features-average ${ }^{\bar{x}}$, standard deviations sx and coefficients of variation. Subsequently the results of the enterprises were compared. Besides simple comparison of descriptive characteristic values, considering the selected type of obtained data, testing the equality of averages was carried out. The purpose of the Student's t-test was to verify statistical significance of differences in averages of individual motivation factors in studied enterprises so that the fact, that detected differences of descriptive characteristics at the selected level of significance $\alpha$ were not caused only by the mistake made by representative sampling, was eliminated. Two-sample $\mathrm{t}$-test was used to test the hypothesis about the equality of averages:

$$
\mathrm{H}_{0}: \mu_{1} \neq \mu_{2}
$$

$\mathbf{H}_{\mathbf{0}}$ : we suppose that averages of studied motivation factors of men are not equal to averages of studied motivation factors of women and at the same time we suppose that the difference between them, if any, is caused only owing to the random variation of results. The random variable $t$ was used as a test criterion. The Student's t distribution was as follows:

- if $\delta_{1}^{2}=\delta_{2}^{2} ; X_{1}$ and $X_{2}$ are independent

$$
t=\frac{\bar{x}_{1}-\bar{x}_{2}}{\sqrt{\frac{n_{1} \cdot s_{1}^{2}+n_{2} \cdot s_{2}^{2}}{n_{1}+n_{2}-2} \cdot \frac{n_{1}+n_{2}}{n_{1} \cdot n_{2}}}}
$$

- if $\delta_{1}^{2} \neq \delta_{2}^{2} ; \mathrm{X} 1$ and $\mathrm{X} 2$ are independent

$$
t=\frac{\bar{x}_{1}-\bar{x}_{2}}{\sqrt{\frac{s_{1}^{2}}{n_{1}-1}+\frac{s_{2}^{2}}{n_{2}-1}}}
$$




\section{Results}

Questionnaires were submitted online to employees in randomly selected enterprises and organisations throughout Slovakia. 4,099 respondents participated in social inquiry (Table 2).

Table 2. The total number of respondents and their characteristics

\begin{tabular}{lc}
\hline Sex & Number \\
\hline Male & 2,090 \\
\hline Female & 2,009 \\
\hline Age & Number \\
\hline up to 30 & 947 \\
\hline $31-40$ & 1,289 \\
\hline $41-50$ & 1,130 \\
\hline $51+$ & 733 \\
\hline Education & Number \\
\hline Primary education & 111 \\
\hline Lower secondary education & 845 \\
\hline Upper secondary education & 2,235 \\
\hline Higher education & 908 \\
\hline Seniority & Number \\
\hline less than 1 year & 390 \\
\hline $1-3$ years & 799 \\
\hline 4-6 years & 851 \\
\hline $7-9$ years & 684 \\
\hline 10 and more years & 1,375 \\
\hline Job position & Number \\
\hline Manager & 387 \\
\hline Blue-collar worker & 2,670 \\
\hline White-collar worker & 1,042 \\
\hline & \\
\hline &
\end{tabular}

Source: Own processing.

Table 3 shows the averages of desired state and state-of-the-art of the motivation of men and women and the difference between them that determines the extent of identifying with the motivation factor by men or by women. Following the values the difference in the level of motivation factors of men and women can be seen.

Table 3. Averages of motivation factors in terms of gender in Slovakia in 2015

\begin{tabular}{|c|c|c|c|c|c|c|c|}
\hline \multirow{3}{*}{ S. $\mathbf{N}$. } & \multirow{3}{*}{ Motivation factor } & \multicolumn{2}{|c|}{ Average } & \multirow{3}{*}{ Difference } & \multicolumn{2}{|c|}{ Average } & \multirow{3}{*}{ Difference } \\
\hline & & $\begin{array}{c}\text { desired } \\
\text { state }\end{array}$ & state-of-the-art & & $\begin{array}{c}\text { desired } \\
\text { state }\end{array}$ & state-of-the-art & \\
\hline & & \multicolumn{2}{|r|}{ male } & & \multicolumn{2}{|r|}{ female } & \\
\hline 1 & $\begin{array}{l}\text { Atmosphere in the } \\
\text { workplace }\end{array}$ & 4.32 & 3.27 & 1.04 & 4.54 & 3.24 & 1.29 \\
\hline 2 & Good work team & 4.35 & 3.47 & 0.88 & 4.42 & 3.49 & 0.93 \\
\hline 3 & Fringe benefits & 4.26 & 2.71 & 1.55 & 4.31 & 2.63 & 1.67 \\
\hline 4 & Physical effort at work & 3.75 & 3.09 & 0.66 & 3.80 & 3.14 & 0.66 \\
\hline 5 & Job security & 4.36 & 3.08 & 1.28 & 4.39 & 3.13 & 1.26 \\
\hline 6 & $\begin{array}{l}\text { Communication in the } \\
\text { workplace }\end{array}$ & 4.14 & 3.18 & 0.96 & 4.31 & 3.23 & 1.08 \\
\hline 7 & Name of the company & 3.75 & 3.31 & 0.44 & 3.90 & 3.34 & 0.57 \\
\hline 8 & $\begin{array}{l}\text { Opportunity to apply } \\
\text { one's own ability }\end{array}$ & 3.92 & 3.04 & 0.89 & 4.03 & 3.14 & 0.89 \\
\hline 9 & $\begin{array}{l}\text { Workload and type of } \\
\text { work }\end{array}$ & 4.05 & 3.21 & 0.84 & 4.12 & 3.31 & 0.81 \\
\hline
\end{tabular}




\begin{tabular}{|c|c|c|c|c|c|c|c|}
\hline 10 & $\begin{array}{l}\text { Information about } \\
\text { performance result }\end{array}$ & 3.85 & 3.03 & 0.82 & 3.94 & 3.12 & 0.82 \\
\hline 11 & Working time & 4.14 & 3.29 & 0.84 & 4.17 & 3.42 & 0.75 \\
\hline 12 & Work environment & 4.09 & 3.11 & 0.98 & 4.20 & 3.31 & 0.89 \\
\hline 13 & Job performance & 4.00 & 3.30 & 0.71 & 4.18 & 3.40 & 0.78 \\
\hline 14 & Career advancement & 3.91 & 3.02 & 0.89 & 4.02 & 3.11 & 0.91 \\
\hline 15 & Competences & 3.80 & 2.82 & 0.97 & 3.89 & 2.94 & 0.95 \\
\hline 16 & Prestige & 3.64 & 2.95 & 0.69 & 3.70 & 2.98 & 0.71 \\
\hline 17 & Supervisor's approach & 4.31 & 3.13 & 1.18 & 4.42 & 3.20 & 1.22 \\
\hline 18 & $\begin{array}{l}\text { Individual decision } \\
\text { making }\end{array}$ & 3.92 & 3.06 & 0.86 & 3.98 & 3.08 & 0.90 \\
\hline 19 & Self-actualization & 3.88 & 2.92 & 0.96 & 3.97 & 3.00 & 0.97 \\
\hline 20 & Social benefits & 4.05 & 2.77 & 1.28 & 4.09 & 2.86 & 1.23 \\
\hline 21 & Fair appraisal system & 4.35 & 2.86 & 1.49 & 4.36 & 2.87 & 1.49 \\
\hline 22 & Occupational safety & 3.97 & 2.77 & 1.20 & 4.13 & 2.73 & 1.40 \\
\hline 23 & Mental effort & 3.92 & 2.83 & 1.09 & 4.06 & 2.82 & 1.23 \\
\hline 24 & $\begin{array}{l}\text { Mission of the } \\
\text { company }\end{array}$ & 3.82 & 2.98 & 0.83 & 3.86 & 3.05 & 0.81 \\
\hline 25 & Region's development & 3.79 & 2.79 & 1.00 & 3.83 & 2.75 & 1.08 \\
\hline 26 & $\begin{array}{l}\text { Education and personal } \\
\text { growth }\end{array}$ & 3.97 & 2.95 & 1.03 & 4.07 & 3.01 & 1.07 \\
\hline 27 & $\begin{array}{l}\text { Relation to the } \\
\text { environment }\end{array}$ & 3.86 & 3.12 & 0.75 & 3.92 & 3.17 & 0.76 \\
\hline 28 & Free time & 4.08 & 3.01 & 1.06 & 4.05 & 3.02 & 1.03 \\
\hline 29 & Recognition & 4.06 & 2.84 & 1.22 & 4.14 & 2.87 & 1.27 \\
\hline 30 & Basic salary & 4.42 & 2.56 & 1.86 & 4.45 & 2.59 & 1.86 \\
\hline
\end{tabular}

Source: Own processing.

Table 4. The most important motivation factors-male, in 2015

\begin{tabular}{|c|c|c|}
\hline S. $\mathbf{N}$. & Motivation factor & Average \\
\hline 1 & Basic salary & 4.42 \\
\hline 2 & Job security & 4.36 \\
\hline 3 & Fair appraisal system & 4.35 \\
\hline 4 & Good work team & 4.35 \\
\hline 5 & Atmosphere in the workplace & 4.32 \\
\hline 6 & Supervisor's approach & 4.31 \\
\hline 7 & Fringe benefits & 4.26 \\
\hline 8 & Communication in the workplace & 4.14 \\
\hline
\end{tabular}

Note. Significantly different motivation factors are in bold.

Source: Own processing.

The order of eight the most important motivation factors for men and women is illustrated in Table 4 and 5 . Dominant motivation factors are similar, however, their sense for men and women are different. The more attention must be paid to mentioned motivation factors when creating motivation programme regardless of job position, age, education and seniority.

Table 5. The most important motivation factors-female, in 2015

\begin{tabular}{clc}
\hline S.N. & \multicolumn{1}{c}{ Motivation factor } & Average \\
\hline 1 & Atmosphere in the workplace & $\mathbf{4 . 5 4}$ \\
2 & Basic salary & 4.45 \\
3 & Supervisor's approach & 4.42 \\
4 & Good work team & $\mathbf{4 . 4 2}$ \\
5 & Job security & 4.39 \\
6 & Fair appraisal system & 4.36 \\
\hline
\end{tabular}




\begin{tabular}{lll}
7 & Communication in the workplace & $\mathbf{4 . 3 1}$ \\
8 & Fringe benefits & 4.31 \\
\hline
\end{tabular}

Note. Significantly different motivation factors are in bold.

Source: Own processing.

Firstly the averages were defined and subsequently the differences in the level of motivation of men and women using the Student's T-test ware analysed. Table 6 shows 18 significantly important motivation factors. The value of $F$ test of these factors is in the critical region C, i.e. $F$ is a subset of $C$ and $P$-value $<0.05$. Owing to the fact that significant differences in 18 motivation factors in terms of male and female were studied in the year 2015 we can state that the importance of the differences in averages is statistically significant. The result of the analysis is that the hypothesis $\mathrm{H}_{0}$ can be accepted. Therefore we can claim, in terms of the importance of individual motivation factors, there are fundamental differences in the level of motivation between male and female in Slovakia.

Table 6. Significant motivation factors

Source: Own processing.

\begin{tabular}{clc}
\hline S. N. & Significant motivation factors & p-level \\
\hline 1 & Atmosphere in the workplace & 0.002 \\
2 & Good work team & 0.006 \\
3 & Communication in the workplace & 0.000 \\
4 & Name of the company & 0.000 \\
5 & Opportunity to apply one's own ability & 0.000 \\
6 & Workload and type of work & 0.004 \\
7 & Information about performance result & 0.004 \\
8 & Work environment & 0.000 \\
9 & Job performance & 0.000 \\
10 & Career advancement & 0.000 \\
11 & Competences & 0.003 \\
12 & Supervisor's approach & 0.000 \\
13 & Individual decision making & 0.043 \\
14 & Self-actualization & 0.001 \\
15 & Occupational safety & 0.000 \\
16 & Mental effort & 0.000 \\
17 & Education and personal growth & 0.000 \\
18 & Recognition & 0.002 \\
\hline
\end{tabular}

Subsequently, Figures 1-18 show averages, deviations and confidence intervals of significant motivation factors using box plots.

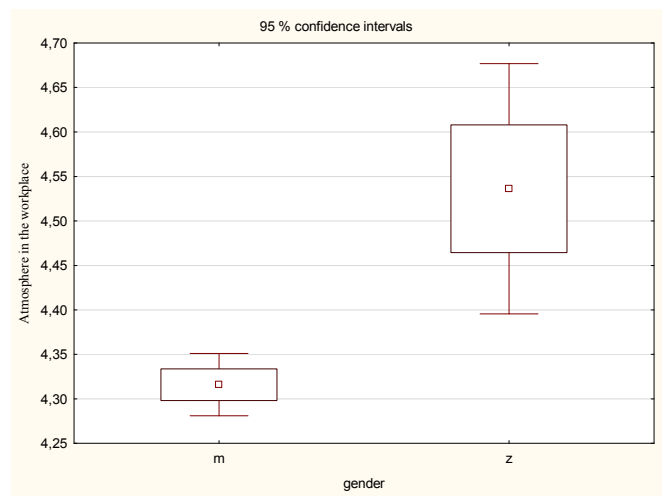

Figure 1. Atmosphere in the workplace

Source: Own processing. 


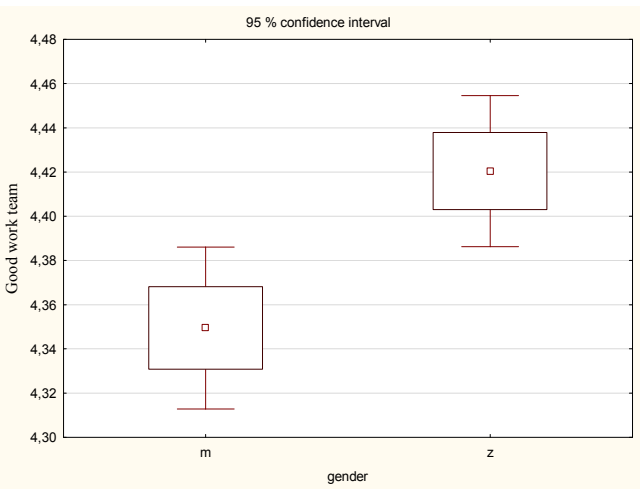

Figure 2. Good work team

Source: Own processing.

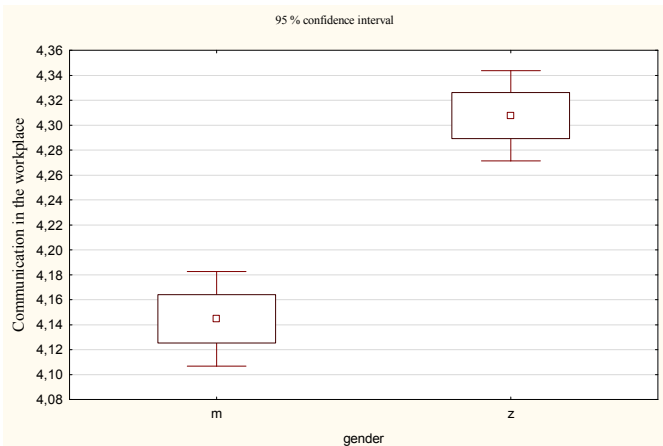

Figure 3. Communication in the workplace

Source: Own processing.

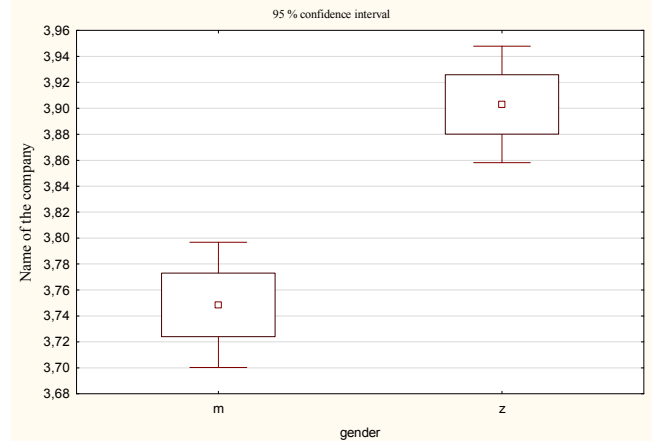

Figure 4. Name of the company

Source: Own processing. 


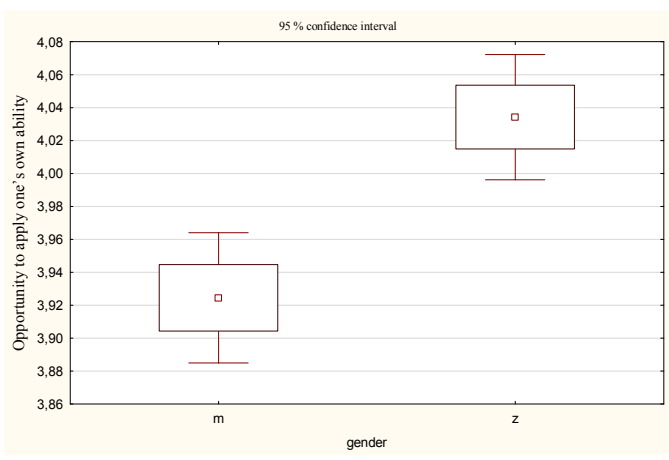

Figure 5. Opportunity to apply one's own ability Source: Own processing

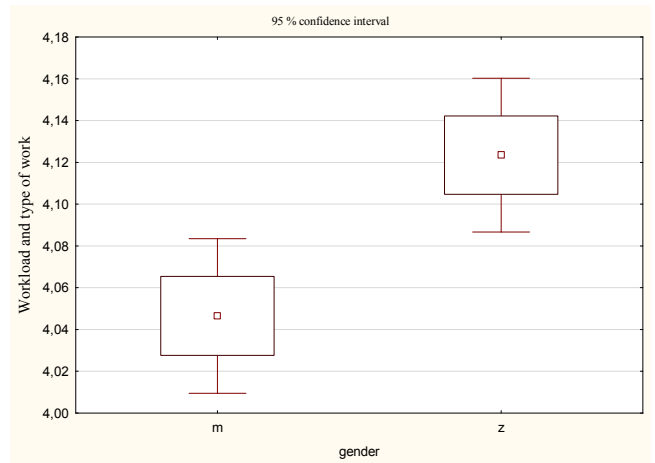

Figure 6. Workload and type of work

Source: Own processing.

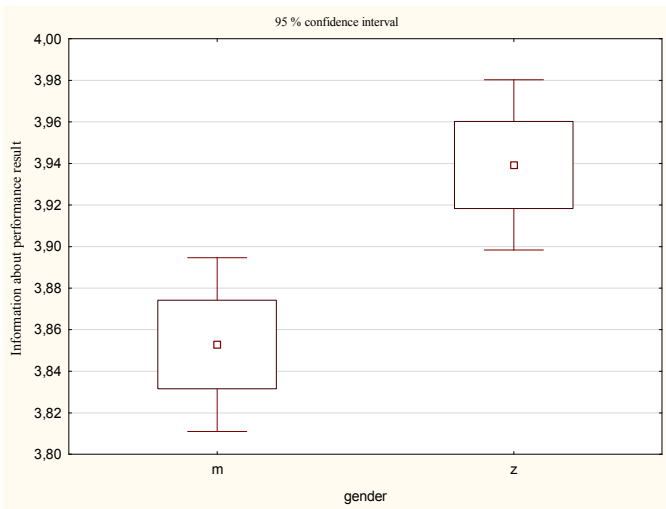

Figure 7. Information about performance result Source: Own processing. 


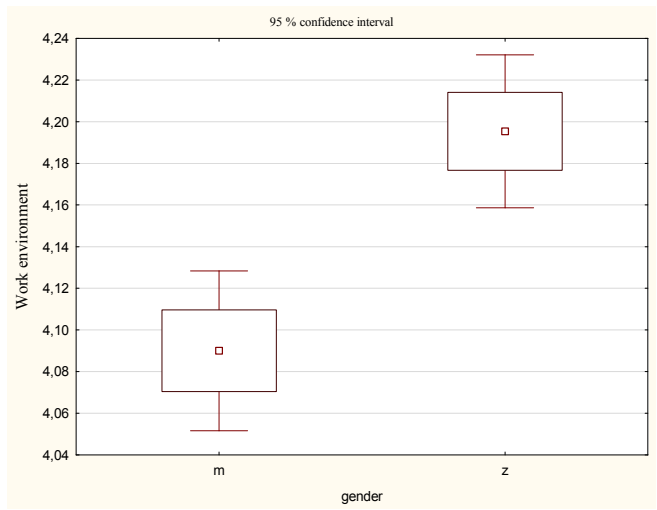

Figure 8 . Work environment

Source: Own processing.

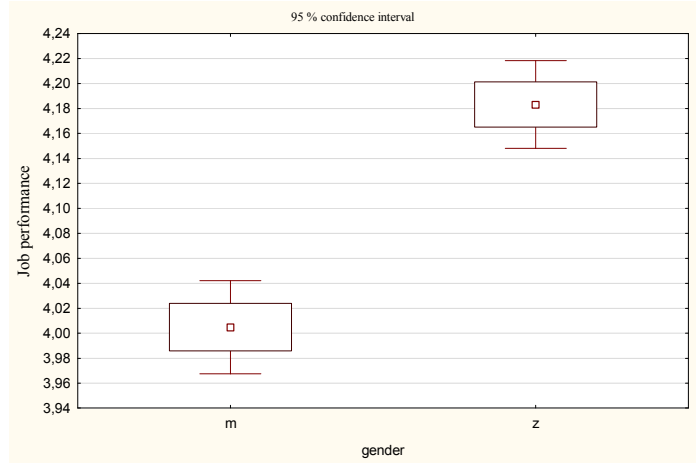

Figure 9. Job performance

Source: Own processing.

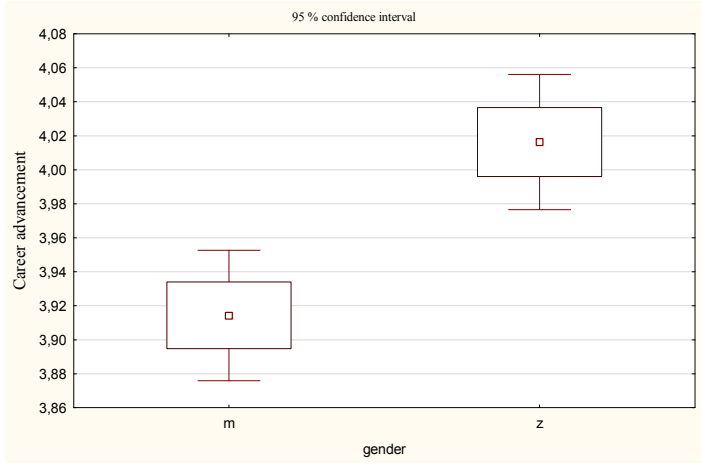

Figure 10. Career advancement

Source: Own processing. 


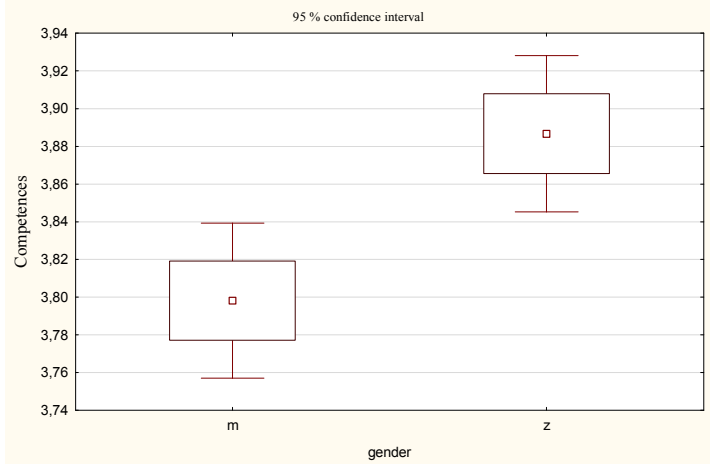

Figure 11. Competences

Source: Own processing.

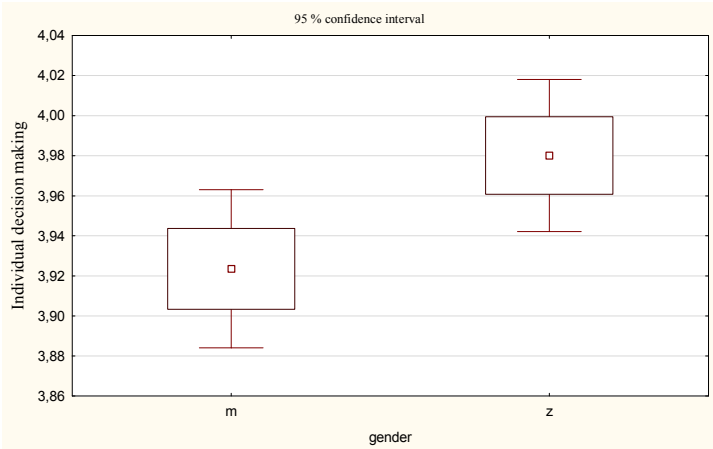

Figure 13. Individual decision making

Source: Own processing.

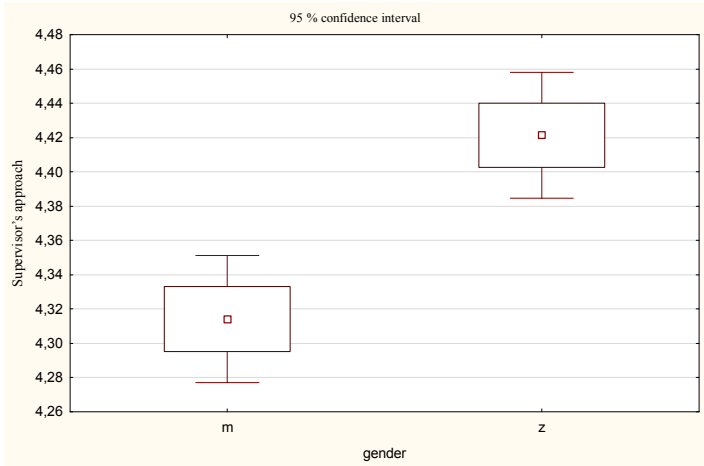

Figure 12. Supervisor's approach

Source: Own processing. 


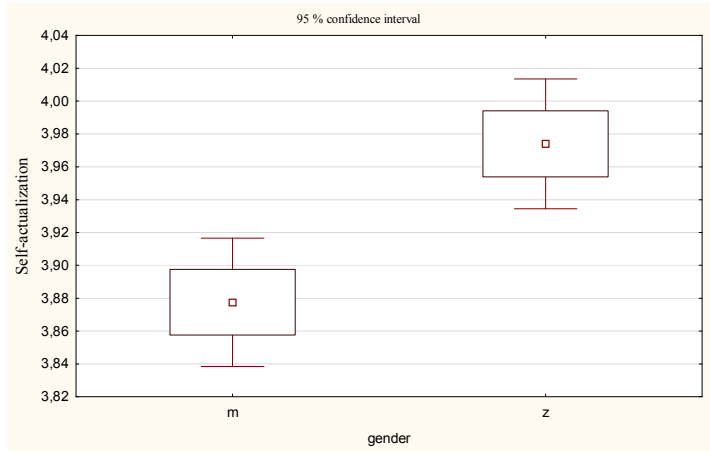

Figure 14. Self-actualization

Source: Own processing.

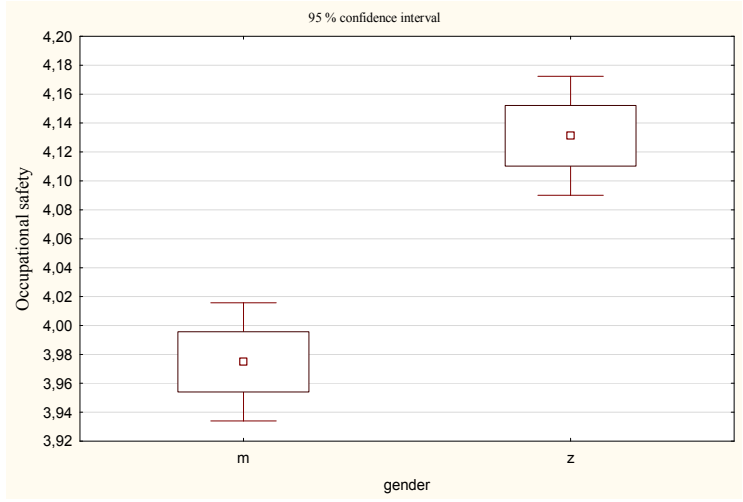

Figure 15. Occupational safety

Source: Own processing.

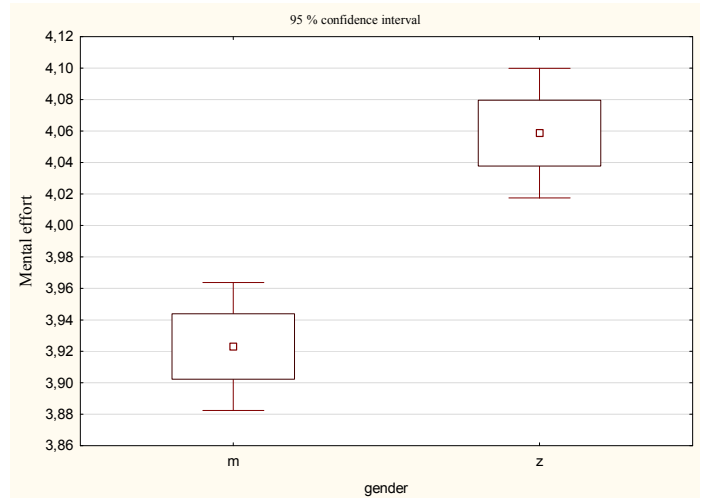

Figure 16. Mental effort

Source: Own processing. 


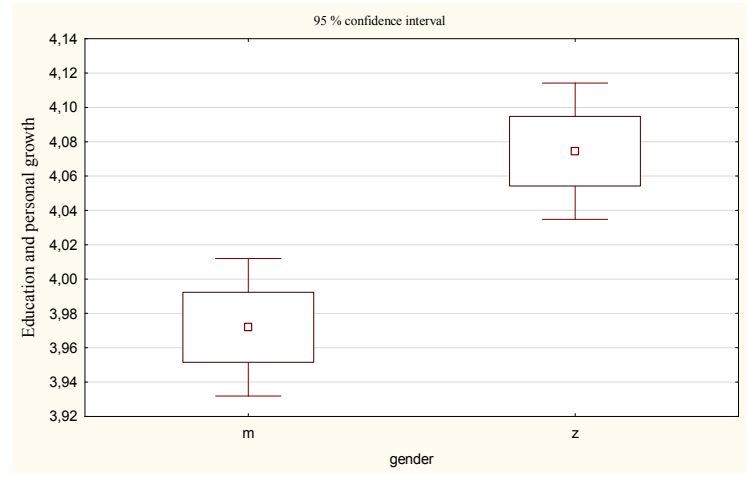

Figure 17. Education and personal growth

Source: Own processing.

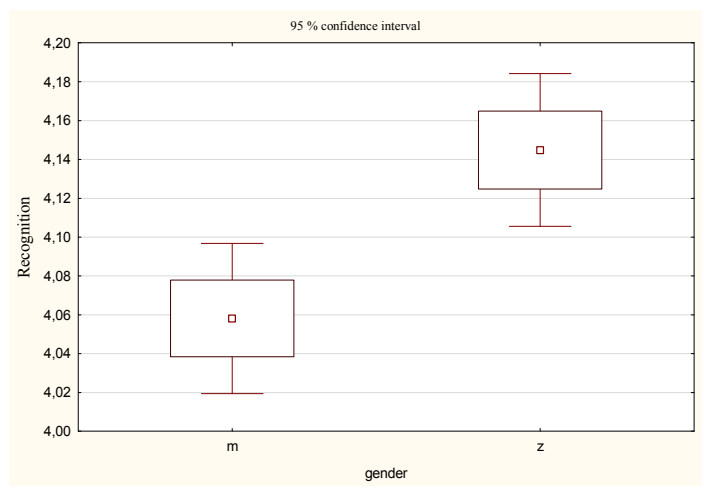

Figure 18. Recognition

Source: Own processing.

\section{Conclusion}

At the present time human resource development must be in the centre of attention of managers in order to improve employee performance (Myšková, 2005; Anwar et al., 2012). Enterprise management as well as staff have an important role in corporate performance management. Human resource departments in enterprises and organisations, where the management understood their position, can become a tool to improve performance (Teplická, 2004). That is also the way to support competitiveness and effectiveness of the enterprise (Kachaňáková \& Urbancová, 2015). Implemented motivation programme is a part of the active enterprise policy. Creating motivation programmes is a difficult and expensive activity for each enterprise (Rajnoha et al., 2015). Its effectiveness is influenced by exact employee analysis. On the basis of actual analyses (Vetráková, M., Hitka, M., \& Sedmák, R., 2007; Závadský et al., 2015; Hitka et al., 2015; Hafiza et al., 2011; Vetráková et al., 2013), we sum up our findings of carried out social inquiries and state that motivation factors of men and women in Slovakia in 2015 are very similar. However, specific differences in the level of motivation in terms of gender must be regarded by reason that it can be strengthened by motivation programme markedly. Despite the fact that unified motivation programme in terms of gender can be created by the enterprise, there are specific differences affecting its effectiveness especially in the decision-making process while managing men and women, especially differences between basic salary and supervisor's approach in the case of women and fair appraisal system in the case of men. Moreover, we can state that all employees are fully aware of the importance of job security and the fact that employers cannot provide employees adequate financial reward during recession. Therefore the enterprises should focus on the motivation using motivation factors based on interpersonal relationship job security. During recession employers tend to increase motivation that is why employee dissatisfaction is at lower level. Effective communication is a tool to create responsible relationship among employees as well as to ensure job security during recession (Kampf et al., 2014). This need is not in the centre of attention of many employers. Moreover, motivation requirements of employees can also change after meeting their needs considering the regional 
differences in Slovakia (Malachovský, 2014). Therefore we suggest the enterprise to update motivational programme from time to time.

\section{Acknowledgement}

This paper has been supported by the project VEGA No. 1/0268/13 "Perspectives of Facility Management Application for the Increasing of Competitiveness within the Wood processing and Forestry Companies in the Context of Outsourcing Principles“.

\section{References}

Fuchsová, K., \& Kravčáková, G. (2004). Manažment pracovnej motivácie. Bratislava: Iris, 170.

Grazulis, V., \& Baziene, B. (2009). Employees' socialization in Lithuanian preschools-myth or reality (situational analysis). Filosofija, Sociologija, 20(4), 344-353.

Hafiza, N. S., Shah, S. S., \& Jamsheed, H. (2011). Relationship between rewards and employee's motivation in the non-profit organizations of Pakistan. In Business Intelligence Journal, 4(2), 1918-2325.

Hitka, M. (2009). Model analýzy motivácie zamestnancov výrobných podnikov. Zvolen: Technická univerzita vo Zvolene.

Hitka, M., \& Balážová, Ž. (2015). The impact of age, education and seniority on motivation of employees. Journal Business: Theory and Practice, 16(1), 113-120. http://dx.doi.org/10.3846/btp.2015.433

Hitka, M., \& Štípalová, L. (2011). Comparing level of employee`s motivation in wood processing businesses with manufacturing companies in Slovak republic. Drvna industria, 62(3), 185-192. http://dx.doi.org/10.5552/drind.2011.1101

Hitka, M., Stachová, K., Balážová, Ž., \& Stacho, Z. (2015). Differences in Employee Motivation at Slovak Primary Schools in Rural and Urban Areas. International education studies, 33-42.

Kachaňáková, A., \& Urbancová, H. (2015). Practical application of selected theoretical knowledge in human resources management. Economic Annals, 2(1).

Kampf, R., \& Bucháčková, P. (2005). User Benefits and Wider Economic Impacts of Infrastructural Project Investment. Journal of Information, Control and Management Systems, 3(2), 91-96.

Kampf, R., \& Ližbetinová, L. (2015). The Identification and Development of Talents in the Environment of Logistics Companies. Publisher: University of Dubrovnik, 62, 139-142. http://dx.doi.org/10.17818/NM/2015/SI9

Kampf, R., Hitka, M., \& Potkány, M. (2014). Interannual differences in employee motivation in manufacturing enterprises in slovakia. Komunikácie, 16(4), 98-102.

Kostiviarová, S., \& Sopková, E. (2009). The evaluation of innovation activities of small and medium-sized business. Perspectives of Innovations in Economics and Business, 3(3-2009), 18-19.

Kropivšek, J., Jelačić, D., \& Grošelj, P. (2011). Motivating employees of Slovenian and Croatian wood industry companies in times of economic downturn. Drvna industrija, 62(2), 97-103. http://dx.doi.org/10.5552/drind.2011.1040

Kucharčíková, A. (2014). The importance of identification and analysis of educational needs for investment in human capital. Komunikacie, 16(3), 86-92.

Malachovský, A. (2014). Goals of tourism development in Slovakia in the context of regional development and selected tourism markets. 17th International Colloquium on Regional Sciences Location: Hustopece, Czech Republic. 17th international colloquium on regional sciences, 787-795.

Myšková, R. (2005). Metodika hodnocení spokojenosti pracovníků. Časopis Ekonomie a management 1/2005. TU Liberec, 84-97.

Potkány, M., \& Stachová, K. (2015). Required skills and abilities of facility manager on strategic level of managing in Slovak companies. Economic Annals-XXI, 3-4(1), 55-59.

Potkány, M., Hajduková, A., \& Teplická, K. (2012). Target costing calculation in the woodworking industry to support demand at the time of global recession. Drewno, 55(187), 89-104.

Rajnoha, R., Lorincová, S., \& Bego, M. (2015). Strategic business performance management system in wood $\begin{array}{lllll}\text { processing industry in Slovakia. Drvna Industrija, 66(2), 137-146. } & \text {. }\end{array}$ http://dx.doi.org/10.5552/drind.2015.1504 
Ramlall, S. (2004). A review of employee motivation theories and their implications for employee retention within organizations. Journal of American Academy of Business, Cambridge, 5(1/2), 52-63.

Scheer, L. (2007). Biometria. Vysokoškolská učebnica. Zvolen: Technická univerzita vo Zvolene.

Shah, A. A., Syed, G., Bhatti, N., Michael, S., Shaikh, F. M., \& Shah, H. (2012). Job Satisfaction of Faculty Members of Universities in Pakistan: A Case Study of University of Sindh-Jamshoro. Modern Applied Science, 6(7), 89-95. http://dx.doi.org/10.5539/mas.v6n7p89

Sharlyn, J. L. (2005). Motivating employees. USA: ASTD Press, 16. Retrieved from https://books.google.sk/books?id=LKd2DOKd1EYC\&printsec=frontcover\&hl=sk\&source=gbs_ge_summa ry_r\&cad $=0 \# \mathrm{v}=$ onepage\&q $\& \mathrm{f}=$ false $>$

Srivastava, S. K., \& Kakkar, D. (2008). Estimation of motivation using entropy. Journal of Business Economics and Management, 9(1), 53-56.

Stacho, Z., Urbancová, H., \& Stachová, K. (2013). Organisational arrangement of human resources management in organisations operating in Slovakia and Czech Republic. Acta Universitatis Agriculturaeet Silviculturae Mendelianae Brunensis, LXI(7), 2787-2799. http://dx.doi.org/10.11118/actaun201361072787

Teplická, K. (2004). Progressive Management Trends in Manufacturing Enterprises. Ekonomie a management, $7(4), 26-31$.

Vaníčková, R. (2015). Corporate personnel policy and personnel strategy. 12th International Scientific Conference HPD, Klaipèda, 27-28.

Vetráková, M., Hitka, M., \& Sedmák, R. (2007). Analýza vývoja motivácie robotníkov v Slovenských elektrárn̆ach a. s. Mochovce z časového a vecného hladiska. Časopis Ekonomie a management 1/2007. TU Liberec, 84-97.

Vetráková, M., Potkány, M., \& Hitka, M. (2013). Outsoucing of Facility management. Časopis E+M. Vyd. Univerzita Liberec, 80-92.

Zámečník, R. (2007). Personnel controlling as a part of the management controlling system in an enterprise. Ekonomie a Management, 10(2), 29-36.

Závadská, Z., Závadský, J., \& Sirotiaková, M. (2013). Process model and its real application in the selected management areas. E a M: Ekonomie a Management, 16(1), 113-127.

Závadský, J., Hitka, M., \& Potkány, M. (2015). Changes of employee motivation of slovak enterprises due to global economic crisis. In E+M. Ekonomie a management. Technická univerzita v Liberci, Ekonomická fakulta, 18(1), 57-66. http://dx.doi.org/10.15240/tul/001/2015-1-005

\section{Copyrights}

Copyright for this article is retained by the author(s), with first publication rights granted to the journal.

This is an open-access article distributed under the terms and conditions of the Creative Commons Attribution license (http://creativecommons.org/licenses/by/3.0/). 